\title{
FOCAL INFECTION IN RHEUMATOID ARTHRITIS
}

\section{A COMPARISON OF THE INCIDENCE OF FOCI OF INFECTIONS IN THE UPPER RESPIRATORY TRACT IN ONE HUNDRED CASES OF RHEUMATOID ARTHRITIS AND ONE HUNDRED CONTROLS}

\author{
BY \\ L. S. P. DAVIDSON, J. J. R. DUTHIE, and MAX SUGAR \\ From the Department of Medicine, University of Edinburgh
}

\begin{abstract}
Although the controversy regarding the aetiological role of focal infection in rheumatoid arthritis has raged for many years, no report has been found in the literature dealing with the incidence of focal infection in this disease as compared with a group of suitable controls examined under similar conditions. Accurate data on this point might be of considerable value in reaching a decision as to the importance of eradicating foci of infection in the treatment of rheumatoid arthritis. Little information is available as to the incidence of foci of infection in healthy people and in patients suffering from diseases other than rheumatoid arthritis.
\end{abstract}

Among 239 psychiatric patients, Brown (1940) discovered infection in the nose and throat in 44 per cent., in the teeth in 37 per cent., and in the urinary tract in 17 per cent. None of these patients suffered from arthritis. A large number of reports have dealt with the subject of focal infection in chronic arthritis. Cecil (1927) stated that foci of infection were present in a very high percentage of patients. The tonsils were infected in 61 per cent. of cases, the teeth in 33 per cent., and the sinuses in 15 per cent. In a later paper with Angevine (1938) it is stated that such foci are of importance in only 20 per cent. of cases and the view is expressed that they are found just as often in patients suffering from other diseases. Pemberton (1920), in a study of four hundred cases of arthritis in soldiers, found demonstrable foci in 73 per cent. In 52 per cent. the tonsils were infected, in 33 per cent. the teeth alone, and in 19.5 per cent. both teeth and tonsils. Wyatt and Bensema (1942), in a series of 343 cases of rheumatoid arthritis, discovered a focus of infection in some situation in 57 per cent. Nisenson (1941) found dental infection in 65 per cent. of 55 cases. In an analysis of 388 cases of rheumatoid arthritis, Sclater (1943) states that focal infection was present in 38 per cent. (147 cases). The tonsils were the commonest site of infection (97 cases). Snyder and others (1932) found the sinuses to be infected in 25 per cent. of 386 cases of chronic arthritis. The infection was usually of an asymptomatic or silent type. They claimed that with few exceptions the arthritis responded favourably to treatment of the diseased sinuses. Hurd (1937) laid great emphasis on the importance of infected sinuses as an aetiological cause of chronic arthritis. He stated that more than two-thirds of his series of cases had already had their tonsils removed without benefit. Treatment of the persistent sinus infection led to improvement in many cases. Bach (1947) analysed the case histories of 286 patients who sought further treatment because of active rheumatoid arthritis. Teeth had been extracted previously in 73 , tonsils had been removed in 118 , sinuses operated on in 7 , and other foci had been dealt with in 14 . Hench (1938) expressed the view that infected foci, especially oral, are probably present in 75 per cent. of people over $\mathbf{4 0}$ who nevertheless remain free from rheumatoid arthritis. Steindler (1934) thought that there are no tonsils in which pathological changes cannot be found after the first year of life.

No attempt has been made to present a complete . review of the voluminous literature on the subject; but it will be seen that foci of infection have loomed very large in the minds of many physicians dealing with chronic arthritis. It is an undoubted fact that foci of infection are frequently found in patients suffering from rheumatoid arthritis, but their aetiological significance remains obscure. In recent years an increasing number of clinicians have adopted the view that a focus of infection is the means whereby tissues become sensitized to bacterial antigens, and that an abnormal immunological response follows any further contact with the original antigen. No satisfactory proof is available that such a sensitizing mechanism is the essential factor underlying the development of rheumatoid arthritis. If, however, it could be shown that a significantly higher incidence of focal infection is present in 
patients suffering from rheumatoid arthritis than in a comparable group of controls, this would lend at least some support to the view that focal infection is of aetiological significance.

The writers accordingly felt that reliable data could best be obtained by submitting an unselected series of cases of rheumatoid arthritis to examination by an experienced ear, nose, and throat surgeon who would also examine a control series consisting of an equal number of persons not suffering from rheumatoid arthritis. Examinations were carried out in the Rheumatic Clinic, Edinburgh Royal Infirmary. Since ear, nose, and throat infections are more prevalent at certain seasons it was arranged to spread the examination of patients and controls throughout the whole of one year so that both groups would be equally affected by seasonal variations. Controls of comparable age and sex were collected from various sources. The majority were drawn from patients attending the Clinic in whom the diagnosis of rheumatoid arthritis could definitely be excluded. A number were suffering from osteo-arthritis, others from post-traumatic lesions, and in a smaller number no evidence of any organic disease could be found. The remainder consisted of patients attending the surgical or orthopaedic out-patient departments for fractures or injuries. One hundred cases of rheumatoid arthritis and one hundred controls were examined. A history of previous disease in the upper respiratory tract was noted in each case, and a swab was taken from the throat and from a tonsillar crypt. The sex and age distribution of patients and controls are shown in Table 1 . There were 29 males and 71 females in each group. Seventeen of the 29 male cases of arthritis and 40 of the 71 female cases (57 per cent. of the total) were between 40 and 60 years of age.

TABLE 1

SEX AND AGE DISTRIBUTION

\begin{tabular}{c|c|c|c|c}
\hline \multirow{2}{*}{$\begin{array}{c}\text { Age } \\
\text { group }\end{array}$} & \multicolumn{2}{c}{ Rheumatoid arthritis } & \multicolumn{2}{c}{ Controls } \\
\cline { 2 - 3 } \cline { 4 - 5 } & Male & Female & Male & Female \\
\hline $10-19$ & - & - & 2 & - \\
$20-29$ & 2 & 8 & 7 & 7 \\
$30-39$ & 5 & 14 & 4 & 12 \\
$40-49$ & 12 & 16 & 7 & 22 \\
$50-59$ & 5 & 24 & 5 & 17 \\
$60-69$ & 4 & 8 & 4 & 11 \\
$70-75$ & 1 & 1 & - & 2 \\
\hline & 29 & 71 & 29 & 71 \\
\hline
\end{tabular}

Incidence of Septic Foci

All cases were examined impartially by the ear, nose, and throat surgeon without reference to the presence or absence of rheumatoid arthritis. Decisions as to the presence of a septic focus were taken solely upon the results of a careful examination of the upper respiratory tract of each case, and the criteria set were those which would be generally acceptable in the ear, nose, and throat department of a teaching hospital. The sinuses were radiographed in every case, but in this investigation proofpuncture was not performed where opacity of the sinuses was demonstrated. It is well recognized that sinus opacity may be due to causes other than chronic infection, and-in the absence of confirmatory evidence obtained by wash-out these cases can only be regarded as having a possible sinus infection.

\section{Rheumatoid Group .}

In the rheumatoid group actual or potential septic foci were discovered in 44 cases. In 37 there was a single focus, and in 7 multiple foci. Thirtyeight showed opacity of sinuses on $x$-ray examination, 11 had infected tonsils, and 4 infected lymphatice tissue in the pharynx.

In 27 cases antral wash-out only was advised Nasal operations of a more radical nature were recommended in 5 cases because of the presence of polypi or purulent discharge. Removal of tonsils was advised in 11 cases, and in 4 others large collections of lymphatic tissue required treatment.

In cases with actual or potential foci of infection in the rheumatoid group the duration of the disease was five years or under in 29 cases, and over five years in the remaining 15 . A history of previous ear, nose, or throat trouble was obtained in 27 cases, but in only 5 was there a definite time relationship to the onset of arthritis (within three months of the onset).

In 56 cases there was no clinical evidence of infection in the ears, nose, or throat. In 39 of these cases the duration of the disease was five years or under, and over five years in the remaining 17. A history of previous infection in the ears, nose, or throat was obtained in 20 cases, but in only 3 was the previous infection related to the onset of arthritis (within three months).

Amongst the 100 cases of rheumatoid arthritis, 7 gave a history of vasomotor rhinitis. In 6 cases the presence of this condition was verified by clinical examination. 


\section{Control Group}

In this group potential or actual foci of infection were present in 43 cases. In 33 there was a single focus, and in 10 multiple foci. In 32 cases antral wash-out was advised, removal of tonsils in 14, and a nasal operation in 5 .

A previous history of ear, nose, or throat infection was obtained in 27 cases. Three cases gave a history of vasomotor rhinitis, but none showed any clinical evidence of this condition on examination.

The data obtained from the two groups are summarized in Table 2.

TABLE 2

INCIDENCE AND SITE OF INFECTED FOCI IN ONE HUNDRED CASES OF RHEUMATOID ARTHRITIS AND ONE HUNDRED CONTROLS

\begin{tabular}{|c|c|c|c|c|c|}
\hline & & & & $\begin{array}{l}\text { Rheumatoid } \\
\text { arthritis }\end{array}$ & Controls \\
\hline Infected fo & present & $\ldots$ & . & 44 & 43 \\
\hline $\begin{array}{l}\text { Single .. } \\
\text { Multiple }\end{array}$ & . & $\begin{array}{l}\cdots \\
\cdots\end{array}$ & $\cdots$ & $\begin{array}{r}37 \\
7\end{array}$ & $\begin{array}{l}33 \\
10\end{array}$ \\
\hline $\begin{array}{l}\text { Sinuses } \\
\text { Tonsils .. } \\
\text { Throat . . } \\
\text { Ears . }\end{array}$ & $\begin{array}{l}\cdots \\
\cdots \\
\cdots\end{array}$ & $\begin{array}{l}\cdots \\
\cdots \\
\cdots\end{array}$ & $\begin{array}{l}\cdots \\
\cdots \\
\cdots\end{array}$ & $\begin{array}{r}38 \\
11 \\
4 \\
-\end{array}$ & $\begin{array}{l}32 \\
14 \\
1\end{array}$ \\
\hline $\begin{array}{c}\text { Operations } \\
\text { Antral } \\
\text { Nasal } \\
\text { Tonsillec } \\
\text { Throat }\end{array}$ & $\begin{array}{l}\text { dvised } \\
\text { h-out } \\
\ldots \\
\text { my } \\
\ldots\end{array}$ & $\begin{array}{l}\cdots \\
\cdots \\
\cdots\end{array}$ & $\begin{array}{l}\cdots \\
\cdots\end{array}$ & $\begin{array}{r}27 \\
5 \\
11 \\
4\end{array}$ & $\begin{array}{r}32 \\
5 \\
14 \\
-\end{array}$ \\
\hline
\end{tabular}

\section{Cell Counts}

Differential counts were made on stained films of the contents expressed from a tonsillar crypt in the majority of cases of both groups, but no significant information was obtained. In 75 cases of rheumatoid arthritis, leucocytes predominated in 64 and lymphocytes in 11 . In 85 controls leucocytes predominated in 67 and lymphocytes in 18.

\section{Bacteriological Examination}

In each case a swab was taken from the tonsil and one from the pharynx and submitted to bacterial investigation. The predominating organisms in both groups were streptococci (haemolytic, nonhaemolytic, and viridans). There was no significant bacteriological difference between the cases of rheumatoid arthritis and the controls.

\section{Discussion}

From this small investigation there appears to be no significant difference in the incidence of infected foci in the upper respiratory tract in cases of rheumatoid arthritis as compared with a group of controls of similar sex and age distribution. The incidence of focal infection, especially in tonsils, is low when compared with the figures of other investigators quoted earlier. Undoubtedly ear, nose, and throat surgeons hold widely different views as to the clinical evidence required to make a diagnosis of an infected focus. In the present investigation, where the same criteria were applied to patients and controls, the comparatively low incidence of infection in the upper respiratory tract is of less significance than the observation that there was no significant difference in the incidence in patients and in controls. The investigation was admittedly incomplete in that, where sinus infection was suggested by opacity on $x$-ray examination, the information obtained by proof puncture was not available to confirm or disprove the presence of infection. This information would undoubtedly have shown that a proportion of cases with sinuses showing opacities on $x$-ray examination were not suffering from infection in this situation. There is no reason, however, to believe that a similar finding would not have been found in the control series. All that can be said with certainty is that the incidence of abnormalities in the sinuses based on radiological examination is similar in the hundred cases of rheumatoid arthritis and in the control series. In the rheumatoid group only eight cases could recall having suffered from an infection of the upper respiratory tract within three months of the onset of the disease. The results obtained in this investigation would not suggest that infection in this situation plays a significant part in the aetiology of rheumatoid arthritis.

\section{Summary}

1. One hundred cases of rheumatoid arthritis and one hundred suitably selected controls have been investigated as to the incidence of septic foci in the upper respiratory tract.

2. Actual or potential foci were found in 44 per cent. of cases of rheumatoid arthritis and in 43 per cent. of controls.

3. Only eight patients in the rheumatoid group gave a history of an infection of the upper respiratory tract within three months of the onset of the arthritis.

4. No significant information was obtained from differential counts of the cells in material 
expressed from a tonsillar crypt nor from bacteriological examination of the tonsils and pharynx which was of value in differentiating the cases of rheumatoid arthritis from the controls.

5. The results obtained do not suggest that infections of the ear, nose, or throat play an important part in the aetiology of this disease.

During this investigation one of the authors (M.S.) was in receipt of a Grant from the Empire Rheumatism Council.

\section{REFERENCES}

Bach, T. F. (1947). “"Arthritis and Allied Conditions." F. A. Davis Coy., Philadelphia.

Brown, C. H. (1940). Amer. Jour. med. Sci., $199,539$.

Cecil, R. L., and Archer, B. H. (1927). Ibid., 173, 258.

$\longrightarrow$, and Angevine, D. M. (1938). Ann. int. Med., $12,577$.

Hench, P. S. (1938). In Gordon, R. G. : “A Survey of the Chronic Rheumatic Diseases." Oxford University Press, London.

Hurd, L. M. (1937). Med. Clin. N. Amer., 21, 1683.

Nisenson, A. (1941). Med. Bull. Vet. Admin., 18, 57.

Pemberton, R. (1920). Arch. int. Med., 25, 231-355.

Sclater, J. G. (1943). Annals of the Rheumatic Diseases, 3, 195.

Snyder, R. G., Fineman, S., and Traeger, C. (1932). Laryngoscope, 42, 682.
Steindler, A. (1934). “Proceedings of the American Medical Association for the Study and ControP of Rheumatic Diseases." Cleveland.

Wyatt, B. L., and Bensema, C. E. (1942). Urol. Cutan? Rev., 46, 113.

Infection Focale dans l'Arthrite- Rhumatismal RÉSUMÉ

Cent cas d'arthrite rhumatismale et cent témoins $\mathrm{s}^{\mathrm{N}}$ convenablement choisis furent examinés en vue d'établit̄ l'incidence des foyers septiques des voies respiratoires supérieures. Des foyers existants ou potentiels furentw trouvés dans 44 pour cent des cas d'arthrite rhumatismale et dans 43 pour cent des témoins. Huit malades seulemen du groupe rhumatismal présentaient une histoire d'in io fection des voies respiratoires supérieures endéans dẹ trois mois précédant le début de l'arthrite.

Le compte cellulaire différentiel fait sur la substancev exprimée des cryptes amygdaliennes et l'examen bactério-윽 logique des amygdales et du pharynx n'ont fourni aucunindice significatif qui permettrait de différentier entrecs les malades atteints d'arthrite rhumatismale et les témoins $-\mathbb{D}$

Les résultats obtenus ne suggèrent guère que les infec-西 tions de l'oreille, du nez ou de la gorge jouent un rôle important dans l'étiologie de cette maladie. 